\title{
Prevalence of Domestic Violence Among the Pregnant Women Attending BPKIHS
}

\author{
Regmi MC ${ }^{1}$, Subedi L ${ }^{2}$, Shrestha $\mathbf{R}^{1}$, Dixit $\mathbf{B}^{1}$, Shrestha $\mathbf{N}^{1}$ \\ ${ }^{1}$ Department of Obstetrics and Gynecology, BPKIHS, Dharan, Sunsari, Nepal. ${ }^{2}$ School of Public Health and Community \\ Medicine, BPKIHS
}

Received: 23-Jan-2017; Accepted: 30-Mar-2017

Aims: To find out the prevalence of domestic violence in pregnant women attending Antenatal clinics (ANC) of B. P. Koirala Institute of Health Sciences, a tertiary centre in eastern Nepal.

Methods: It was a hospital based cross-sectional study done at antenatal clinics of BPKIHS from 14th March 2015 to 30 th August 2015. The total number of recruited antenatal patients was 470 . Data were collected by face to face interview via pretested semi-structured questionnaire. Descriptive and inferential statistics were used for data analysis.

Results: The prevalence of domestic violence among pregnant women was $53.2 \%$ of which prevalence of physical domestic violence was $9.6 \%$. The most common person inflicting the domestic violence was husband (23.6\%). Emotional abuse was the most common form of domestic violence experienced by the pregnant women $(26.8 \%)$ and threatening for remarriage was most common emotional violence faced $(43.2 \%)$. As the age of the pregnant women increases, they tend to have more domestic violence.

Conclusions: The prevalence of domestic violence among pregnant women seemed alarmingly high in our society. Awareness to the family members and strengthening the women empowerment at community level might play a major role for reducing such violence. Pregnancy-related violence is a serious public health issue.

Keywords: ANC clinics, domestic violence, physical threats, psychological abuse.

DOI: http://dx.doi.org/10.3126/njog.v12i1.18978

\section{INTRODUCTION}

Domestic violence (DV) extends beyond physical acts of violence towards one's partner to include sexual coercion, physical threats, psychological abuse and controlling actions such as physical isolation or restricting access to health care or financial resources. ${ }^{1}$ In recent years, domestic violence during pregnancy is given much attention due to its prevalence, adverse health consequences and intervention potential.

Domestic violence during pregnancy endangers both the pregnant woman and her unborn child. In pregnancy domestic violence can have a number of adverse outcomes on maternal and neonatal health, including, poor nutrition, miscarriage, antepartum hemorrhage, premature labor, trauma, placental abruption, low birth weight, maternal deaths and still births. $^{2}$

Domestic violence is a form of violence against women and when it involves pregnant women, it calls for a closer attention because of the greater danger

\section{CORRESPONDENCE}

Dr. Mohan Chandra Regmi, BPKIHS, Dharan, Sunsari, Nepal Phone: +977-9852049414,

Email: mohanchallo@yahoo.com it entails. ${ }^{3}$ Besides health effects, domestic violence impedes women's economic and social development and capacity for self-determination and the adverse health consequences affecting women and their children. ${ }^{4}$ The prevalence of violence against women ranged between $17-37 \%$ with considerable regional variation. $^{5-8}$ The impact of domestic violence on pregnant women is increasingly recognized as an important public health issue that has serious consequences for their physical and mental health. This study attempts to document the prevalence, knowledge and perception of domestic violence among pregnant women attending BPKIHS.

This study was conducted to find out the prevalence of domestic violence in pregnant women attending Antenatal clinics (ANC) of B. P. Koirala Institute of Health Sciences, a tertiary centre in Eastern Nepal.

\section{METHODS}

It was a hospital based cross-sectional study done among 470 pregnant women in antenatal clinics of BPKIHS between March to August 2015. The women were selected by purposive sampling among those attending ANC clinics of BPKIHS. Data were collected by face to face interview via pre-tested semistructured questionnaire. Data were entered in MS 
Excel Sheet and converted into SPSS 17.1 version for further analysis. Descriptive and inferential statistics were used for data analysis.

\section{RESULTS}

Among 470 pregnant women recruited in the study, 273 women had experienced the domestic violence resulting the prevalence of domestic violence to be $58.1 \%$ out of which $53.2 \%$ women had experienced domestic violence for the first time in this pregnancy. Majority of the women $(n=126$,
26.8\%) had experienced emotional abuse which was the most common form of domestic violence among pregnant women. A total of 45 women had experienced physical domestic violence resulting in the prevalence of physical domestic violence as $9.6 \%$. Majority of the women $(n=111,23.6 \%)$ inflicting the domestic violence was the husband. Threatening for remarriage $(n=118,43.2 \%)$ was the most common emotional violence faced (Table 1).

Table 1: Problems faced due to Domestic Violence during pregnancy $(n=470)$.

\begin{tabular}{|c|c|c|c|}
\hline Characteristics & Category & Frequency & Percentage \\
\hline \multirow[t]{3}{*}{ Type of DV experienced } & Physical & 45 & 9.6 \\
\hline & Emotional & 126 & 26.8 \\
\hline & Word Abuse & 102 & 21.7 \\
\hline \multirow[t]{3}{*}{ How often faced DV } & Almost daily & 41 & 8.7 \\
\hline & Sometimes & 173 & 36.8 \\
\hline & Rarely & 59 & 12.6 \\
\hline \multirow[t]{3}{*}{ Who do DV on you } & Husband only & 111 & 23.6 \\
\hline & All family member & 88 & 18.7 \\
\hline & In-laws & 74 & 15.7 \\
\hline \multirow{5}{*}{$\begin{array}{l}\text { Pregnancy related } \\
\text { complication }\end{array}$} & Unintended pregnancy & 5 & 1.8 \\
\hline & Induced abortion & 21 & 7.7 \\
\hline & Psychological & 162 & 59.3 \\
\hline & Vaginal bleeding & 33 & 12.1 \\
\hline & Chronic pelvic pain & 52 & 12.1 \\
\hline \multirow{7}{*}{$\begin{array}{l}\text { Emotional violence } \\
\text { faced }\end{array}$} & Back Biting & 16 & 5.9 \\
\hline & Verbal abuse & 85 & 31.1 \\
\hline & Threatened to remarriage/ sending to parents home & 118 & 43.2 \\
\hline & Blamed of induced abortion & 24 & 8.8 \\
\hline & Accused of witchcraft & 1 & 0.4 \\
\hline & Not allowed to seek health care & 6 & 2.2 \\
\hline & Not allowed to enter in kitchen for household chores & 23 & 8.4 \\
\hline Total & & 470 & 100 \\
\hline
\end{tabular}

Table 2: Reproductive Health problems and its association with Domestic Violence ( $\mathrm{n}=\mathbf{2 7 3}$ ).

\begin{tabular}{|c|c|c|c|c|c|}
\hline \multirow{2}{*}{ Characteristics } & \multirow{2}{*}{ Categories } & \multicolumn{2}{|c|}{ If experienced DV at home during pregnancy } & \multirow{2}{*}{ P-value } & \multirow[t]{2}{*}{ Remarks } \\
\hline & & Yes & No & & \\
\hline \multirow{2}{*}{ Have you ever aborted } & Yes & $125(74.9 \%)$ & $42(25.1 \%)$ & \multirow{3}{*}{$<0.001$} & \multirow{3}{*}{ Sig } \\
\hline & No & $148(48.8 \%)$ & $155(51.2 \%)$ & & \\
\hline Total & & $273(58.1 \%)$ & $197(41.9 \%)$ & & \\
\hline \multirow{3}{*}{ Cause of abortion } & Spontaneous & $31(59.6 \%)$ & $21(40.4 \%)$ & \multirow{4}{*}{$<0.001$} & \multirow{4}{*}{ Sig } \\
\hline & Forceful & $65(95.6 \%)$ & $3(4.4 \%)$ & & \\
\hline & Medical & $29(61.7 \%)$ & $18(38.3 \%)$ & & \\
\hline Total & & $125(74.9 \%)$ & $42(25.1 \%)$ & & \\
\hline \multirow{3}{*}{ Reason of abortion } & Sex selection & $19(95 \%)$ & $1(5 \%)$ & \multirow{3}{*}{0.374} & \\
\hline & Financially poor & $8(88.9 \%)$ & $1(11.1 \%)$ & & \multirow[b]{2}{*}{ Not sig } \\
\hline & Unwanted by family & $38(97.4 \%)$ & $1(2.6 \%)$ & & \\
\hline Total & & $65(95.6 \%)$ & $3(4.4 \%)$ & - & - \\
\hline
\end{tabular}


A total of 125 women (74.9\%) who had aborted had experienced domestic violence during the pregnancy $(p<0.001)$. In majority of the women $(n=65,95.6 \%)$, the cause of abortion was forceful $(\mathrm{p}<0.001)$ (Table $2)$. Majority of the patients $(n=98,69 \%)$ facing the domestic violence was of age group 30-40 years and above $(\mathrm{p}<0.001)$. As the age of the patient increases, they tend to have more domestic violence as shown in this study (Table 3).

Table 3: Relation of Domestic Violence during pregnancy with Socio-demographic characteristics $(\mathrm{n}=470)$,

\begin{tabular}{|c|c|c|c|c|c|}
\hline \multirow{2}{*}{ Characteristics } & \multirow{2}{*}{ Categories } & \multicolumn{2}{|c|}{ if experienced DV at home during pregnancy } & \multirow{2}{*}{ p-value } & \multirow{2}{*}{ Remarks } \\
\hline & & Yes & No & & \\
\hline \multirow{3}{*}{ Age (in years) } & $15-20$ & $23(39.0 \%)$ & $36(61.0 \%)$ & \multirow{3}{*}{$<0.001$} & \multirow{3}{*}{ sig } \\
\hline & $21-30$ & $152(56.5 \%)$ & $117(43.5 \%)$ & & \\
\hline & $30-40$ and above & $98(69 \%)$ & $44(31 \%)$ & & \\
\hline \multirow{4}{*}{ Occupation } & Housewife & $168(57.3 \%)$ & $125(42.7 \%)$ & \multirow{4}{*}{0.956} & \multirow{4}{*}{ Not sig } \\
\hline & Job & $57(60.6 \%)$ & $37(39.4 \%)$ & & \\
\hline & Business & $29(58 \%)$ & $21(42 \%)$ & & \\
\hline & Student & $19(57.6 \%)$ & $14(42.4 \%)$ & & \\
\hline \multirow{4}{*}{ Educational status } & Uneducated & $33(66 \%)$ & $17(34 \%)$ & \multirow{4}{*}{0.590} & \multirow{4}{*}{ Not sig } \\
\hline & Primary & $30(61.2 \%)$ & $19(38.8 \%)$ & & \\
\hline & Secondary & $48(55.2 \%)$ & $39(44.8 \%)$ & & \\
\hline & SLC and above & $162(57 \%)$ & $122(43 \%)$ & & \\
\hline \multirow{3}{*}{ If husband working } & Yes & $261(58.7 \%)$ & $184(41.3 \%)$ & \multirow{3}{*}{0.294} & \multirow{3}{*}{ Not sig } \\
\hline & No & $12(48 \%)$ & $13(52 \%)$ & & \\
\hline & $<1$ year & $25(41 \%)$ & $36(59 \%)$ & & \\
\hline \multirow[t]{2}{*}{ Duration of marriage } & $2-5$ years & $128(60.7 \%)$ & $83(39.3 \%)$ & \multirow[t]{2}{*}{0.23} & \multirow[t]{2}{*}{ Not sig } \\
\hline & $>5$ years & $120(60.6 \%)$ & $78(39.4 \%)$ & & \\
\hline \multirow{5}{*}{$\begin{array}{l}\text { Educational level of } \\
\text { husband }\end{array}$} & Uneducated & $15(65.2 \%)$ & $8(34.8 \%)$ & \multirow{5}{*}{0.425} & \multirow{5}{*}{ Not sig } \\
\hline & Non formal education & $26(65 \%)$ & $14(35 \%)$ & & \\
\hline & Primary & $29(67.4 \%)$ & $14(32.6 \%)$ & & \\
\hline & Secondary & $83(54.2 \%)$ & $70(45.8 \%)$ & & \\
\hline & Higher education & $120(56.9 \%)$ & $91(43.1 \%)$ & & \\
\hline \multirow{2}{*}{ Family size } & Nuclear & $130(62.5 \%)$ & $78(37.5 \%)$ & \multirow{2}{*}{0.084} & \multirow{2}{*}{ Not sig } \\
\hline & Joint & $143(54.6 \%)$ & $119(45.4 \%)$ & & \\
\hline Total & & 273 & 197 & - & - \\
\hline
\end{tabular}

\section{DISCUSSION}

In this study, the prevalence of domestic violence among pregnant women was $58.1 \%(\mathrm{n}=273)$ which is similar to the study conducted by Jahanfar et $\mathrm{al}^{9}$ $(60.6 \%)$. In this study, age was highly significant to domestic violence during pregnancy where as in a similar study done in Parsa by Pradhan ${ }^{10}$, the age variable had no association with the experience of gender based violence. The most common person inflicting the domestic violence was the husband $(n=111,23.6 \%)$ in this study. Similarly, a systematic review of 13 studies from several African countries (including Nigeria, Rwanda, South Africa, Uganda and Zimbabwe) done by Shamu et $\mathrm{al}^{11}$ showed that $23-40 \%$ of pregnant women experienced physical violence by an intimate partner. Having patriarchal nature in the culture might be the probable reasons for the high prevalence by partner in this study.
The most common form of domestic violence experienced by the pregnant women was emotional abuse $(n=126,26.8 \%)$ in this study. Similarly, the prevalence of physical domestic violence in this study was $9.6 \%(n=45)$ which is consistent with the study done by Babu et $\mathrm{al}^{12}$ in which the prevalence of physical domestic violence during pregnancy was $8.3 \%$. Perhaps because of potential links between pregnant women's physical injury during pregnancy and injury to the developing fetus, much research has focused on the prevalence of physical violence during pregnancy. Less is known about the prevalence of other types of violence during pregnancy, such as emotional or sexual violence. Although estimates concerning emotional and sexual violence during pregnancy vary, there does appear to be a common pattern: the prevalence of emotional violence is generally greater than the prevalence of physical violence. $^{13}$ 
In this study, 36.8\% $(\mathrm{n}=173)$ pregnant women reported that they sometimes experienced domestic violence during their pregnancy which is consistent with the study done among 1215 women presenting to abortion clinics in China by Wu et $\mathrm{al}^{14}$ which showed that majority of the women regularly experienced domestic violence, including during their current pregnancies. In this study, 43.2\% $(n=118)$ pregnant women were threatened of remarriage or sending back to parents' home and it was the most common emotional violence experienced. This is in contrast to the study done by Gurung et $\mathrm{al}^{15}$ in which $79.2 \%$ women experienced psychological violence out of which $2.2 \%$ of women were threatened to or ever send to their parents' house.

In this study, $74.9 \%(n=125)$ of the pregnant women who had aborted had experienced domestic violence during the pregnancy and the most common cause of abortion was forceful $(n=65,95.6 \%)$ while unwanted child by family was the most common reason for abortion $(n=38,97.4 \%)$. Similarly, the study done in India by Stephenson et $\mathrm{al}^{16}$ showed that women who experienced physical violence have significantly higher odds of reporting a subsequent induced abortion, whereas women who had an induced abortion have significantly higher odds of reporting subsequent sexual and verbal violence.

As the age of the patient increased, they tend to have experienced more domestic violence as shown in this study. But in contrast, the studies done by Cokkinides et $\mathrm{al}^{17}$ and Saltzman et $\mathrm{al}^{18}$ found that women younger than 20 years old were three to four three times more likely than women aged 30 or older to experience violence during pregnancy. Due to low level of education, low income and being dependent on their male partner there might be the higher prevalence of domestic violence with increase in age. In this study, illiterate victims experienced more domestic violence $(n=33,66 \%)$ than literate victims which is much similar to the study done by Pradhan ${ }^{10}$ in which illiterate victims (72.9\%) experienced more violence than literate victims.

\section{CONCLUSIONS}

Pregnancy-related violence is a serious public health issue. The prevalence of domestic violence among pregnant women was found to be higher. Although there is a growing body of research on this subject, there are still many unanswered questions regarding the prevalence of this type of victimization, the risk factors, and the consequences.

\section{REFERENCES}

1. WHO report finds domestic violence is widespread and has serious impact on health. Geneva: World Health Organisation 2005.

2. Campbell D. A Question of Maternal Health. WIN 2010;18(9):53-55. Available from: https://inmo.ie/tempDocs/ Domestic\%20Violence 53-55.pdf

3. Ameh N, Abdul MA. Prevalence of domestic violence amongst pregnant women in Zaria, Nigeria. Annals Afr Med. 2004;3(1):4-6.

4. Tamang J. Domestic Violence in Nepal. SNV Nepal: Socia Inclusion Research Fund;2009.45 p.

5. Bacchus L, Bewley S, Gillian M. Domestic violence and pregnancy. Obstet Gynecol. 2001;3:56-9.

6. Kwawukume EY, Kwawukume SB. Violence against pregnant women- the patient's perspective. Nigerian Journal of Clinical Practice. 2001;4:76-9.

7. Frederickson HL, Wilkins-Haug L Comprehensive prenatal care. In: Obstetrics and Gynecology secrets. Hanley and Blefus, Philadelphia. 1998;162-163.

8. Ikeme ACC, Ezegwu HU, Onwasoigwe CW. Domestic violence against pregnant Nigerian women. Trop J Obstets Gynaecol. 2001;18(1):42.

9. Jahanfar S, Malekzadegan Z. The prevalence of domestic violence among pregnant women who were attended in iran university of medical science hospitals. J Fam Violence. 2007;22(8):643-8.

10. Pradhan N. Prevalence of gender-based violence among pregnant women attending antenatal clinic at Health Institutions. Parsa District : Pokhara University; 2011. 54 p.
11. Shamu S, Abrahams N, Temmerman M, Musekiwa A, Zarowsky C. A systematic review of African studies on intimate partner violence against pregnant women: Prevalence and risk factors. PLoS One. 2011;6(3): e17591.

12. Babu BV, Kar SK. Abuse against women in pregnancy: a population-based study from Eastern India. WHO South-East Asia Journal of Public Health. 2012;1(2):133-43

13. Perales MT, Cripe SM, Lam N, Sanchez SE, Sanchez E, Williams MA. Prevalence, types, and pattern of intimate partner violence among pregnant women in Lima, Peru. Violence Against Women. 2009;15(2):224-250. [PubMed]

14. Wu J, Guo S, Qu C. Domestic violence against women seeking induced abortion in China. Contraception. 2005;72(2):11721.

15. Gurung S, Acharya J. Gender-based violence among pregnant women of syangja district, Nepal. Osong Public Health Res Perspect. 2016;7(2):101-7.

16. Stephenson R, Jadhav A, Winter A, Hindin M. domestic violence and abortion among rural women in four indian States. Violence Against Women. 2016:22(13): 1642-58.

17. Cokkinides VE, Coker AL, Sanderson M, Addy C, Bethea L. Physical violence during pregnancy: Maternal complications and birth outcomes. Obstet Gynecol. 1999;93(5):661-6.

18. Saltzman LE, Johnson CH, Gilbert BC, Goodwin MM. Physical abuse around the time of pregnancy: An examination of prevalence and risk factors in 16 states. Maternal Child Health J. 2003;7(1):31-43. 